International Research Journal of Management, IT \& Social Sciences
Available online at https://sloap.org/journals/index.php/irjmis/
Vol. 6 No. 6, November 2019, pages: 239 243
ISSN: 2395-7492
https://doi.org/10.21744/irjmis.v6n6.800

\title{
Impact of Organizational Justice Perceptions and Transformational Leadership Role on Counter Productive Work Behavior
}

\author{
Ida Ayu Mahesta Yogasari ${ }^{\text {a }}$ \\ I Gusti Ayu Nyoman Budiasih ${ }^{\mathrm{b}}$
}

Article history:

Received: 27 July 2019

Accepted: 30 September 2019

Published: 13 November 2019

\section{Keywords:}

counter-productive work behavior;

interactional justice;

leadership;

procedural justice;

transformational leadership;

\begin{abstract}
This study examines the impact of organizational justice perceptions and transformational leadership role on counterproductive work behavior. The study illustrates that organizational justice (procedural and interactional justice) perception and transformational leadership produces a negative impact on counterproductive work behavior (organizational and interpersonal). The reduction utilizes social exchange theory. Survey methods and purposive sampling methods was conducted by collecting primary data from respondents working as an accounting team member in the Food and Beverage sector of the Badung Regency. The primary data were processed with a multiple linear regression model. Survey results reveal that procedural justice and interactional justice as well as transformational leadership significantly impact counterproductive work behavior (organizational and interpersonal).
\end{abstract}

2395-7492@ Copyright 2019. The Author. This is an open-access article under the CC BY-SA license (https://creativecommons.org/licenses/by-sa/4.0/) All rights reserved.

\section{Author correspondence:}

Ida Ayu Mahesta Yogasari,

Faculty of Economics and Business Udayana University, Denpasar, Indonesia.

Email address: mahesta.yogasari@gmail.com

\section{Introduction}

Counterproductive work behavior indicated by employees will be inclined susceptible to job stress affect employee productivity and leave the workplace as an option (O'Leary-Kelly et al., 1996) and (Novrianti \& Santoso, 2014). Sudarmawan \& Putra (2017), provides further support that job stress affects staff retention.

Organizational justice plays an important role in determining the level of counterproductive work behavior. Organizational perceptions concerning justice experienced by employees in the workplace are related to performance results expressed by counterproductive work behavior. Situations, where employees experience unfair treatment in the organization, can lead to negative emotions and counterproductive behaviors (Fox et al., 2001).

Transformational leadership has been suggested as being a substantial element contributing to employees' work behavior (Bernard et al., 2003). Pradipa et al., (2016), also recommend that thoroughly transformational leadership encourages employees possible to produce a better quality financial statement. When individuals experience the presence of transformational leadership, they feel satisfied with the quality of the relationship and are motivated to

a Udayana University, Denpasar, Indonesia

${ }^{\mathrm{b}}$ Udayana University, Denpasar, Indonesia 
show a positive work attitude which enhances positive work behavior, in particular, increased productivity and job satisfaction.

Previous studies have shown varied results on the relationship of organizational justice, transformational leadership, and counterproductive work behavior. Other previous studies assert organizational justice perception by employees affects counterproductive work behavior. The Procedural justice dimension is considered the best predictor to predict counterproductive work behavior (Cohen-Charash \& Spector, 2001). The interactional justice dimension is considered as the best predictor in predicting counterproductive work behavior (Aquino et al., 1999). Another study demonstrates that transformational leadership does not significantly restrain counterproductive work behavior (Novrianti \& Santoso, 2014).

This study asserts that organizational factors facilitate the control of counterproductive work behavior. This empirical research might be enhanced by the availability of a validated measure of counterproductive work behavior. The purpose of this study is to enrich research variety to reduce such negative behavior for increasing work productivity.

\section{Hypotheses Development}

The Impact of procedural justice on the counter-productive work behavior

Social exchange theory (SET) is among the most influential conceptual paradigms for understanding workplace behavior. The social exchange involves a series of interactions that create an obligation. Procedural justice significantly impacts negatively the counter-productive work behavior either addressed to the organization or to an interpersonal relationship (Cohen-Charash \& Spector, 2001; Novrianti \& Santoso, 2014; Martini et al., 2018). When employees experience a perceived low level of procedural justice in the organization, they will reciprocate by showing counterproductive work behavior.

H1: Procedural justice has a negative impact on counter-productive work behavior (a) addressed to the organization and $(b)$ to interpersonal.

The Impact of interactional justice on the counter-productive work behavior

Previous research has examined that interactional justice has a significant negative impact on the counter-productive work behavior addressed either to the organization or to interpersonal (Akremi et al., 2010; Novrianti \& Santoso, 2014; Farrastama et al., 2019).

H2: Interactional justice has a negative impact on counter-productive work behavior (a) addressed to the organization or (b) to interpersonal.

Transformational Leadership Role on the counter-productive work behavior

Transformational leadership has been proven to contribute to employee perceptions affecting employee's tendencies towards their work attitude or work behavior in the organization. It demonstrated positive results production such as satisfaction on the job, effectiveness, development of behavior and work transparency (Bass et al., 2003; Ngodo, 2008; Pradipa et al., 2016; Putra \& Rasmini, 2018). Transformational leadership effectively decreases the level of counterproductive work behavior when the employees recognize procedural and interactional justice well (Novrianti \& Santoso, 2014).

H3: Transformational leadership has a negative impact on counter-productive work behavior (a) addressed to the organization or (b) to interpersonal.

\section{Materials and Methods}

The population in this study are accounting team members working in the Food and Beverage sector. The criteria of respondents are they must have worked for at least one year. Procedural justice uses 5 items (Niehoff \& Moorman, 1993). Interactional justice uses 10 items (Niehoff \& Moorman, 1993). Transformational leadership uses 20 items (Bass \& Avolio, 1995). And counterproductive work behavior uses 19 items (Bennett \& Robinson, 2000). The collected data is tested by multiple linear regression analysis. 
Descriptive Statistic

Table 1

Minimum, maximum, mean and deviation standard

\begin{tabular}{lllllc}
\hline Variable & Sample & Minimum & Maximum & Mean & Std. Deviation \\
\hline PJ & 95 & 5.00 & 20.00 & 14.63 & 4.44 \\
IJ & 95 & 10.00 & 39.18 & 28.95 & 8.82 \\
TL & 95 & 20.00 & 79.37 & 57.98 & 17.68 \\
CPWO & 95 & 6.00 & 22.53 & 11.64 & 5.57 \\
CPWI & 95 & 13.00 & 54.27 & 28.13 & 11.51 \\
\hline
\end{tabular}

PJ=Procedural Justice; IJ=Interactional Justice; TL=Transformational Leadership

$\mathrm{CPWO}=$ Counterproductive Work addressed to Organization; CPWI=Counterproductive Work addressed to Interpersonal

Hypotheses Testing

Table 2

The impact of procedural justice, interactional justice and transformational leadership on counter-productive work behavior addressed to organizational

\begin{tabular}{lllll}
\hline Variable & $\begin{array}{l}\text { Standardized } \\
\text { Coefficient }(\beta)\end{array}$ & $\mathrm{t}$ & Sig. & Remark \\
\hline Procedural Justice & -0.330 & -4.228 & 0.000 & Significant \\
Interactional Justice & -0.308 & -3.922 & 0.000 & Significant \\
Transformational Leadership & -0.338 & -4.325 & 0.000 & Significant \\
Adjusted $R$ Square $=0.754$ & & & & \\
$\mathrm{~F}=96.995$ & & & & \\
Sig. $=0.000$ & & & & \\
\hline
\end{tabular}

Table 3

The impact of procedural justice, interactional justice and transformational leadership on counter-productive work behavior addressed to interpersonal

\begin{tabular}{lllll}
\hline Variable & $\begin{array}{l}\text { Standardized } \\
\text { Coefficient }(\beta)\end{array}$ & $\mathrm{t}$ & $\mathrm{N}$ Sig. & Remark \\
\hline Procedural Justice & -0.373 & -4.977 & 0.000 & Significant \\
Interactional Justice & -0.339 & -4.497 & 0.000 & Significant \\
Transformational Leadership & -0.276 & -3.674 & 0.000 & Significant \\
Adjusted $R$ Square $=0.773$ & & & & \\
$\mathrm{~F}=107.950$ & & & & \\
Sig. $=0.000$ & & & & \\
\hline
\end{tabular}

\section{Results and Discussions}

Hypothesis 1 is supported. Perception related to procedural justice can encourage employee's involvement in counterproductive work behavior. When employees perceive a better quality of treatment given by their superiors through work delivery related information and procedures, their tendency to engage in counterproductive work behavior is lower. Being part of the organization with procedural justice can increase positive work performance. The test results correspond to previous studies by Fox et al., (2001); Akremi et al., (2010); Novrianti \& Santoso (2014), which illustrate the negative impact between procedural justice and counterproductive work behavior.

Hypothesis 2 is supported. Perception of interactional justice can encourage employee's involvement in counterproductive work behavior. When employees perceive a better quality of treatment given by their superiors

Yogasari, I. A. M., \& Budiasih, I. G. A. N. (2019). Impact of organizational justice perceptions and transformational leadership role on counter productive work behavior. International Research Journal of Management,

IT and Social Sciences, 6(6), 239-243. https://doi.org/10.21744/irjmis.v6n6.800 
through establish interpersonal relationships when procedures and decisions are implemented, the tendency to engage in counterproductive work behavior lower. In a daily workplace, superiors are considered responsible for creating the interactional justice environment. The test results correspond to previous studies by Fox et al., (2001); Akremi et al., (2010); Aquino et al., (1999); Novrianti \& Santoso, (2014), outlining the negative impact between interactional justice and counterproductive work behavior.

Hypothesis 3 also supported. Transformational leadership affects counterproductive work behavior in the workplace. Employee involvement in counterproductive work behavior both aimed at the organization and interpersonal reduces. The impact is stronger when perceived transformational leadership is higher. Based on transformational leadership support theory, the present of transformational leadership will encourage better employee relations by strengthening mutual cooperation, attitude, trust and allowing team learning processes. A number of previous research papers by Boerner et al., (2007); Tse et al., 2014), revealed transformational leadership impacts employees to produce higher performance beyond expectations of initial goals and their personal interest.

\section{Conclusion}

The result of this study brings some practical implications. First, create an atmosphere of fairness in the workplace through establishing procedures and demonstrating respect to an employee's dignity when communicating a decision. Second, an employee's level of trust in an organization is a very important element in reducing counterproductive work behavior.

Counterproductive work behavior can be triggered by perceived perceptions of fairness and the presence of transformational leadership by accountants both received from the organization and from figures representing the organization. Accounting practitioners who can perceive organizational justice well have a tendency not to engage in work behavior that is detrimental to the organization or other members of the organization. While the transformational leadership that is applied provides an opportunity for accountants to be able to express opinions related to work so that they get an assessment that they have been treated fairly.

The results of this study can add to the literature on counterproductive work behavior, organizational justice, and transformational leadership. The dimensions of organizational justice and transformational leadership can produce behavioral consequences with different goals or objectives in different cultural contexts. Through the results of this study are known that by creating a fair job environment, from the formulation of policies in each organization to reduce counterproductive work behavior. Also, the importance of the implications of transformational leadership in order to continue to feel part of the organization to support accounting practitioners to produce better performance.

\section{Conflict of interest statement}

The authors declared that they have no competing interests.

\section{Statement of authorship}

The authors have a responsibility for the conception and design of the study. The authors have approved the final article.

\section{Acknowledgments}

The authors would like to thank the reviewer for their consideration of the further process of the present paper. Thanks to the editor of IRJMIS for the valuable support, time as well as advice. 


\section{References}

Aquino, K., Lewis, M. U., \& Bradfield, M. (1999). Justice constructs, negative affectivity, and employee deviance: A proposed model and empirical test. Journal of Organizational Behavior, 20(7), 1073-1091. https://doi.org/10.1002/(SICI)1099-1379(199912)20:7\%3C1073::AID-JOB943\%3E3.0.CO;2-7

Bass, B. M., \& Avolio, B. J. (1995). MLQ multifactor leadership questionnaire technical report. Binghamton University, NY: Center for Leadership Studies.

Bass, B. M., Avolio, B. J., Jung, D. I., \& Berson, Y. (2003). Predicting unit performance by assessing transformational and transactional leadership. Journal of applied psychology, 88(2), 207.

Bennett, R. J., \& Robinson, S. L. (2000). Development of a measure of workplace deviance. Journal of applied psychology, 85(3), 349. https://psycnet.apa.org/doi/10.1037/0021-9010.85.3.349

Bernard, A., Delplace, J. C., Perry, N., \& Gabriel, S. (2003). Integration of CAD and rapid manufacturing for sand casting optimisation. Rapid Prototyping Journal, 9(5), 327-333. https://doi.org/10.1108/13552540310502220

Boerner, S., Eisenbeiss, S. A., \& Griesser, D. (2007). Follower behavior and organizational performance: The impact of transformational leaders. Journal of Leadership \& Organizational Studies, 13(3), 15-26. https://doi.org/10.1177\%2F10717919070130030201

Cohen-Charash, Y., \& Spector, P. E. (2001). The role of justice in organizations: A meta-analysis. Organizational behavior and human decision processes, 86(2), 278-321. https://doi.org/10.1006/obhd.2001.2958

El Akremi, A., Vandenberghe, C., \& Camerman, J. (2010). The role of justice and social exchange relationships in workplace deviance: Test of a mediated model. Human Relations, 63(11), 1687-1717. https://doi.org/10.1177\%2F0018726710364163

Farrastama, D. N., Asmony, T., \& Hermanto, H. (2019). Effect of emotional intelligence on counterproductive work behavior with job stress as an intervening variable. International Journal of Social Sciences and Humanities, 3(1), 1425. https://doi.org/10.29332/ijssh.v3n1.248

Fox, S., Spector, P. E., \& Miles, D. (2001). Counterproductive work behavior (CWB) in response to job stressors and organizational justice: Some mediator and moderator tests for autonomy and emotions. Journal of vocational behavior, 59(3), 291-309. https://doi.org/10.1006/jvbe.2001.1803

Martini, L. K. B., Suardana, I. B. R., \& Astawa, I. N. D. (2018). Dimension Effect of Tangibles, Reliability,

Responsiveness, Assurance, Empathy, Leadership towards Employee Satisfaction. International Research Journal of

Management, IT and Social Sciences, 5(2), 210-215.

Ngodo, O. E. (2008). Procedural justice and trust: the link in the transformational leadership-organizational outcomes relationship. International Journal of Leadership Studies, 4(1), 82-100.

Niehoff, B. P., \& Moorman, R. H. (1993). Justice as a mediator of the relationship between methods of monitoring and organizational citizenship behavior. Academy of Management journal, 36(3), 527-556. https://doi.org/10.5465/256591

Novrianti, D., \& Santoso, C. B. (2014). The Role of Transformational Leadership as a Moderating Variable for the Relationship of Justices and Counter-Productive Work Behavior at the Public Organization. In Materi disajikan dalam Proceedings of Annual Tokyo Business Research Conference.

O'Leary-Kelly, A. M., Griffin, R. W., \& Glew, D. J. (1996). Organization-motivated aggression: A research framework. Academy of management review, 21(1), 225-253. https://doi.org/10.5465/amr.1996.9602161571

Pradipa, N. A., Putri, I. A. D., \& Ratnadi, M. D. (2016). Gaya Kepemimpinan Transformasional dalam Hubungan Sistem Pengendalian Intern dan Kualitas Laporan Keuangan Pemerintah Daerah (Studi pada Skpd Provinsi Bali). E-Jurnal Ekonomi dan Bisnis Universitas Udayana.

Putra, I. M. E. L., \& Rasmini, N. K. (2018). Style of leadership and organizational culture as moderator of influence of competence and internal control system towards report quality. International Research Journal of Management, IT and Social Sciences, 5(3), 22-34.

Sudarmawan, P. S. K., \& Putra, I. N. W. A. (2017). Pengaruh Role Stress Pada Turnover Intentions Auditor dengan Komitmen Afektif Sebagai Variabel Pemoderasi. E-Jurnal Akuntansi, 2000-2027.

Tse, H. H., Huang, X., \& Lam, W. (2014). " Why does transformational leadership matter for employee turnover? A multi-foci social exchange perspective": Corrigendum.

Yogasari, I. A. M., \& Budiasih, I. G. A. N. (2019). Impact of organizational justice perceptions and transformational leadership role on counter productive work behavior. International Research Journal of Management, IT and Social Sciences, 6(6), 239-243. https://doi.org/10.21744/irjmis.v6n6.800 